\title{
ACRL:n informaatiolukutaidon kehykset korkeakoulukirjastoissa Suomessa ja Yhdysvalloissa
}

\author{
Kati Syvälahti \\ Helsingin yliopiston kirjasto \\ kati.syvalahti@helsinki.fi \\ http://orcid.org/0000-0002-6890-188X \\ Janika Asplund \\ Tampereen yliopiston kirjasto \\ janika.asplund@uta.fi \\ http://orcid.org/0000-0003-1017-5464
}

\begin{abstract}
This article discusses the international IL framework in the Finnish academic library context. In our online questionnaire conducted in May 2017, we researched how Finnish academic libraries in the universities and universities of applied sciences have received the Information literacy framework launched by The ACRL (Association of College and Research Libraries) in 2015. In the article, we discuss the current awareness of the frames in Finland and show practical examples of using the frames. The usefulness as well as the pros and cons of the frames are being analyzed. This article compares the current interpretation of the frames in Finland with the recent discussion in the academic libraries in the United States. Moreover, we address the transition from the IL standards to the Information literacy framework, and discuss similarities in the themes discussed in the States and Finland. Our conclusion was that in Finland, the majority of the libraries are aware of the IL frames and some of the libraries have already used the framework in developing information literacy in higher education.
\end{abstract}

Asiasanat: informaatiolukutaito; korkeakoulukirjastot; korkeakouluopetus; osaaminen; opetustavoitteet; tiedonhankinta 
Informaatiolukutaidon kehyksen (The Framework for Information Literacy for Higher Education) julkaisi Yhdysvalloissa The Association of College and Research Libraries vuonna 2015. Ennen informaatiolukutaidon kehyksen julkaisemista informaatiolukutaidon standardit (ACRL, 200o) ovat olleet laajasti käytössä informaatiolukutaidon käsitteen määrittelyssä ja kirjastojen tiedonhankinnan opetustyössä. Yhteistä informaatiolukutaidon käsitteen erilaisille määritelmille on tiedonhankinnan, -hallinnan ja -käytön taitojen kuvaaminen. Suomessa työtä informaatiolukutaidon kehyksen tunnetuksi tekemiseksi on tehty esimerkiksi Suomen tieteellisen kirjastoseuran Informaatiolukutaitotyöryhmän järjestämissä seminaareissa. Vuoden 2016 seminaarissa oli työpaja IL-kehyksistä (Syvälahti, 2016b). Kansainväliset IL-kehykset suomalaisissa korkeakoulukirjastoissa -kyselyn tuloksista kerrottiin vuoden 2017 seminaarissa (Syvälahti \& Asplund, 2017c). Ranskan Saint-Malossa ECIL 2017 (The European Conference on Information Literacy) -konferenssissa oli esitys suomalaisen kyselyn tuloksista (Syvälahti \& Asplund, 2017b, 2017a). Pedaforum-päivillä 2016 ja 2017 on ollut myös informaatiolukutaidon kehyksiin liittyviä esityksiä (Sipilä, Miettinen, \& Tevaniemi, 2017; Syvälahti, 2016a).

Kati Syvälahti Helsingin yliopiston kirjastosta ja Janika Asplund Tampereen yliopiston kirjastosta toteuttivat toukokuussa 2017 sähköisen kyselyn, jonka tavoitteena oli selvittää, miten IL-kehykset on otettu vastaan korkeakoulukirjastoissa Suomessa. Motivaationa kyselyn tekemiseen toimi artikkelin kirjoittajien käytännön työ yliopisto-opiskelijoiden tiedonhankinnan opettajina. Kyselyn tavoitteena oli kerätä tietoa kirjastojen tiedonhankinnan koulutuksista sekä tarkastella IL-kehyksiä suhteessa IL-standardeihin. Kun kyselyä toteutettiin, olivat IL-kehykset olleet Suomessa vielä melko vähän esillä, joten kyselyn tarkoituksena oli myös herättää keskustelua ja tietoisuutta IL-kehyksistä sekä tarjota mahdollisuus jakaa hyviä käytänteitä.

Kyselyyn tuli vastauksia 31 korkeakoulukirjastosta. Verkkolomake lähetettiin yliopisto- ja ammattikorkeakoulukirjastojen johtajille sähköpostilistojen avulla. Kysely oli avoinna toukokuussa 2017 ja jokaisesta korkeakoulukirjastosta vastattiin kerran. Kirjastonjohtajat joko vastasivat kyselyyn itse tai välittivät kyselyn vastattavaksi informaatiolukutaidon opetuksen asiantuntijoille omassa kirjastossaan. Verkkolomakkeen kysymykset olivat englanniksi ja kyselyyn sai vastata suomeksi, ruotsiksi tai englanniksi. Tietoa korkeakoulukirjastojen näkemyksistä informaatiolukutaidon kehykseen kerättiin avoimilla ja strukturoiduilla kysymyksillä. Tutkimuskysymykset olivat: 
- Mitkä ovat/mikä on informaatiolukutaidon opetuksen kohderyhmä(t)?

- Miten tiedonhankinnan opetus on toteutettu esim. lähiopetus atkluokassa tai verkkokurssi?

- Ovatko informaatiolukutaidon standardit tai informaatiolukutaidon kehykset tutut organisaatiossanne?

- Onko IL-standardeja tai IL-kehyksiä hyödynnetty opetuksen suunnittelussa?

- Miten hyvin IL-kehykset kuvaavat opiskelijoiden tarvitsemia taitoja?

- Onko tulevaisuudessa organisaationne tarkoitus hyödyntää IL-kehyksiä opetuksen suunnittelussa?

- Mikä on kurssien suunnittelun kannalta keskeisin IL-kehys?

\section{IL-standardit tiedonhankinnan opetuksen perustana Suomessa}

Syvälahden ja Asplundin toteuttamassa kyselyssä kerättiin tietoa suomalaisten korkeakoulukirjastojen tiedonhankinnan opetuksesta. ACRL:n vuonna 2000 julkaisemat informaatiolukutaidon standardit (The Information Literacy Competency Standards for Higher Education) ovat olleet tärkeä työkalu integroitaessa informaatiolukutaidon opetusta osaksi korkeakouluopiskelijoiden opintoja. Informaatiolukutaidon opintosuunnitelma -hankkeessa vuonna 2004 annettiin kirjastoille suomeksi käännetyistä IL-standardeista suositus informaatiolukutaidon integroimiseksi korkeakouluopintoihin. SYN (Suomen yliopistokirjastojen neuvosto) ja AMKIT-konsortio (Ammattikorkeakoulujen kirjastoyhteistyökonsortio) laativat yhteisen suosituksen vuonna 2013. Tällöin ulotettiin suositus koskemaan myös jatko-opiskelijoiden tiedonhankinnan opetusta. (Syvälahti \& Asplund, 2015, s. 10.) Kirjastojen asiantuntijat ovat hyödyntäneet informaatiolukutaidon standardeja keskusteltaessa tiedekuntien tai laitosten kanssa tiedonhankinnan opetuksesta. IL-standardien pohjalta on laadittu informaatiolukutaidon opetussuunnitelmia ja oppimistavoitteita. Niitä on hyödynnetty opiskelijoiden osaamisen arvioinnissa. IL-standardit ovat olleet myös ammatillisen keskustelun väline. Niiden avulla suomalaisten korkeakoulukirjastojen asiantuntijoiden ja alan tutkijoiden on ollut mahdollista osallistua kansainväliseen keskusteluun ja tutkimukseen.

Syvälahden ja Asplundin toteuttamassa kyselyssä ilmeni, että vastanneista korkeakoulukirjastoista 30:ssä eli 97 \%:ssa tunnettiin ACRL:n vuonna 2000 jul- 


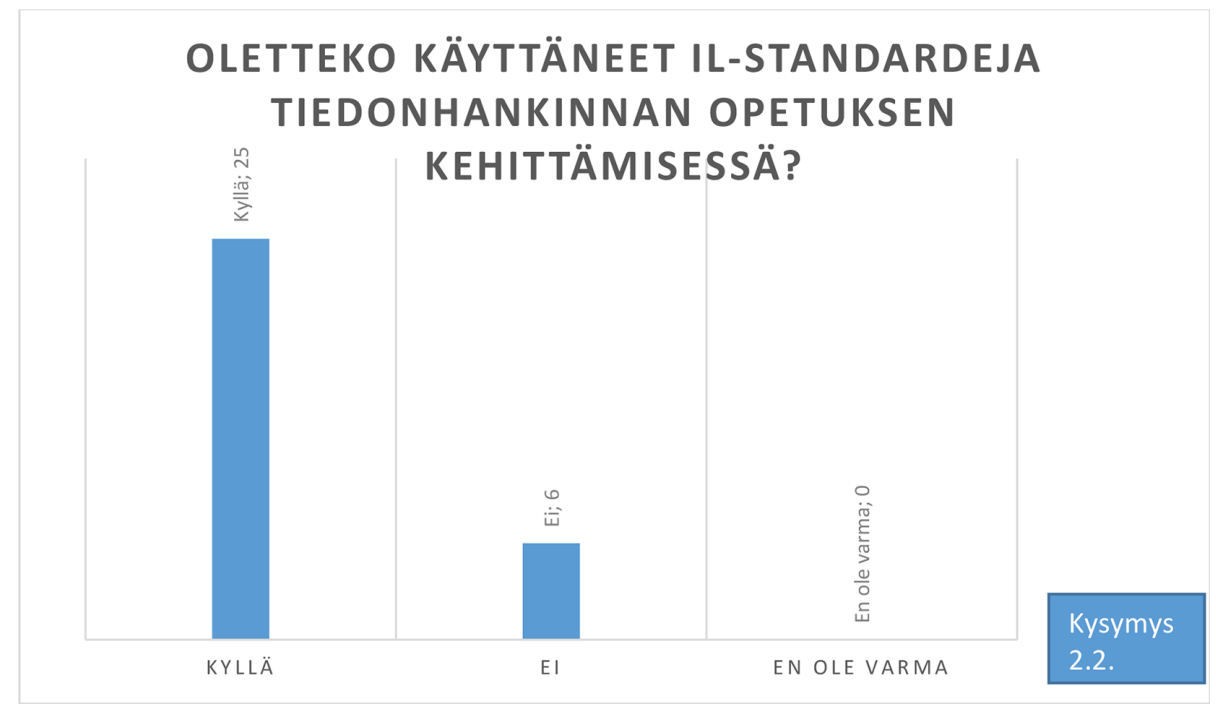

Kuva 1: IL-standardien hyödyntäminen opetuksen kehittämisessä.

kaisemat informaatiolukutaidon standardit. Opetuksen suunnittelussa (Kuva 1) standardeja oli hyödyntänyt $81 \%$ kirjastoista (25 vastaajaa).

Tiedonhankinnan opetusta on integroitu korkeakoulujen opetussuunnitelmiin, mikä on vakiinnuttanut kirjastojen tarjoamaa opetusta osaksi opiskelijoiden opintoja. Yksi kyselyn vastaajista kuvasi IL-standardien merkitystä: “Olemme aikanaan todella perusteellisesti tutustuneet IL-standardeihin ja huomioineet ne suunnitellessamme tiedonhankinnan opetusta."

Informaatiolukutaidon opetuksen on integroinut kattavasti opetussuunnitelmiin 20 korkeakoulua (65 \% vastaajista) ja kymmenessä korkeakoulussa ( $32 \%$ vastaajista) opetus on integroitu osittain. Sanallisissa vastauksissa nousi esiin, että korkeakoulukirjastoissa opetusta annetaan opintojen eri vaiheissa esimerkiksi ensimmäisenä vuonna, kandidaatti- ja maisteriopinnoissa sekä tohtoriopinnoissa. Tiedonhankinnan opetusta on integroitu opintoihin esimerkiksi opintopisteellisinä kursseina tai osana seminaaria tai muuta opintojaksoa, kuten metodikurssia tai tieteellisen kirjoittamisen kurssia. Korkeakoulukirjastojen tarjoama opetus on pakollista tai vapaaehtoista opiskelijoille.

Kaikki kyselyyn vastanneet korkeakoulukirjastot tarjoavat tiedonhankinnan ja -hallinnan opetusta ensimmäisen vuoden opiskelijoille. Kirjastoista 30 eli $97 \%$ vastaajista tarjoaa opetusta kandidaattivaiheen opiskelijoille. Maisterivaiheen opiskelijoille opetusta tarjoaa $94 \%$ eli 29 vastaajaa. Lisäksi opetusta tarjotaan kansainvälisille opiskelijoille (29 kirjastoa eli $94 \%$ vastaajista) ja avoimen yliopiston opiskelijoille ( 21 kirjastoa eli 68 \% vastaajista). Myös opettajille ja tut- 
kijoille tarjotaan opetusta (29 kirjastoa eli $94 \%$ vastaajista). Tutkijakoulutettaville opetusta on 17 kirjastossa ( $55 \%$ vastaajista).

Kyselyssä nousi esiin, että kirjastojen tarjoama tiedonhankinnan opetus on monimuotoista. Kaikki järjestävät lähiopetusta luokkahuoneessa ja neuvontaa asiakaspalvelussa. Henkilökohtaisia ohjauksia tarjottiin 30 kirjastossa. Lisäksi tiedonhankintaa opetetaan luentosaleissa (30 vastaajaa) ja verkkokursseilla (26 vastaajaa eli $84 \%$ vastaajista).

\section{Muutos standardeista kehyksiin}

ACRL:n vuonna 2015 julkaisemia informaatiolukutaidon kehyksiä analysoitaessa kannattaa tarkastella niitä suhteessa ACRL:n vuonna 2000 julkaisemiin informaatiolukutaidon standardeihin, jotka ovat kansainvälisesti hyvin tunnettuja. IL-standardeilla on ollut kiistatta keskeinen rooli informaatiolukutaidon tunnetuksi tekemisessä ja kirjastojen opetuksen kehittämisessä.

Informaatiolukutaidon standardeja on vuosien varrella kritisoitu eri tavoin. Informaatiolukutaidon standardien julkaisemisesta on kuitenkin kulunut yli 15 vuotta ja tietoympäristö on muuttunut sinä aikana monimuotoisemmaksi. Ensimmäinen kritiikin aihe on ollut standardien suuri määrä, koska ne sisältävät 5 osaamistavoitetta (standards) ja 22 suoritusindikaattoria (performance indicators). Toiseksi standardit ovat eritasoisia, sillä osa kuvaa hyvin laajoja ja osa hyvin pieniä osaamisalueita. (Keller, 2016, ss. 28-29.) Kolmanneksi Carol Kuhlthaun mukaan IL-standardeissa korostuvat liikaa erilaiset taitolistaukset. Hän kaipaa laajempaa oppimiseen ja opetukseen liittyvää näkökulmaa. (Kuhlthau, 2013, s. 92.) Nancy M. Foasberg ja James Elmborg korostavat myös pedagogista näkökulmaa ja opiskelijoiden aktiivista roolia. Heidän mukaansa ILstandardeissa korostuu liikaa 1900-luvun merkittävimmän pedagogiikan uudistajan Paulo Freiren kritisoima pankkikasvatus, joka ohjaa opiskelijoita passiiviseen tiedon vastaanottamiseen. (Elmborg, 2006, ss. 192-193; Foasberg, 2015, s. 707 ja 710.) Neljäntenä kritiikin aiheena Kimmo Tuominen, Reijo Savolainen ja Sanna Talja nostavat esiin informaatiolukutaidon sosiaalisen (sociotechnical practice) ja ryhmässä toimimisen aspektin. He kritisoivat IL-standardien korostavan informaatiolukutaitoa yksilösuorituksena. (Tuominen, Savolainen, \& Talja, 2005, s. 330 ja 338.) Informaatiolukutaidon standardien saamasta kritiikistä johtuen ACRL julkaisi informaatiolukutaidon kehyksen vuonna 2015 ja uuden dokumentin tarkoituksena on olla itsenäinen, ei päivitetty versio informaatiolukutaidon standardeista. (Foasberg, 2015, s. 713.)

Yhdysvalloissa keskustelu informaatiolukutaidon kehyksen (ACRL, 2015b) käyttöönotosta on ollut vilkasta eikä ristiriidoilta ole vältytty. Erityisesti ACRL 
Board of Directorsin kesäkuussa 2016 tekemä päätös luopua kokonaan informaatiolukutaidon standardeista on herättänyt voimakkaita mielipiteitä. (Bombaro, 2016, ss. 557-558; Dempsey, Dalal, Dokus, \& Charles, 2015, ss. 165-167; Keller, 2016, s. 4; Seeber, 2015, s. 158.) Tammikuussa 2015 Yhdysvalloissa 352 kirjastoalan asiantuntijaa allekirjoitti vetoomuksen "Open Letter Regarding the Framework for lnformation Literacy for Higher Education", jolla vastustettiin IL-standardien korvaamista IL-kehyksillä. Avoimessa kirjeessä toivottiin, että IL-standardit ja IL-kehykset toimisivat jatkossa rinnakkain. Informaatiolukutaidon kehys sai avoimessa kirjeessä osakseen kritiikkiä liiallisesta teoreettisuudesta ja kirjastoalan "jargonista". (Charles, 2017, ss. 221-222; Dalal, 2015; Keller, 2016, s. 30.)

Megan Oakleafin mukaan muutos standardeista kehyksiin on huomattava. Informaatiolukutaidon standardien hyödyllisyyttä ja tärkeyttä voidaan perustella laajasti käytössä olevilla osaamistavoitteilla. IL-standardien laatimisessa on hyödynnetty Benjamin Bloomin taksonomiaa, joka on tunnettu tapa laatia opetuksen osaamistavoitteita. Bloomin taksonomiassa olennaista on käyttää aktiivisia verbejä kuten tunnistaa, verrata, analysoida ja soveltaa. Informaatiolukutaidon kehyksessä Bloomin taksonomiaa ei ole huomioitu. Osaamistavoitteita kaivataan myös kehyksiin, jotta niitä voisi käyttää opetuksen suunnitteluun. (Dempsey ym., 2015, s. 168; Oakleaf, 2014, ss. 510-510.)

\section{Teoreettiset ja pragmaattiset lähestymistavat informaatiolukutaidon kehykseen}

Syvälahden ja Asplundin toteuttamassa kyselyssä kävi ilmi (Kuva 2), että suomalaisissa korkeakoulukirjastoissa ACRL:n vuonna 2015 julkaisemat informaatiolukutaidon kehykset olivat tutut $71 \%$ :lle kirjastoista (22 vastaajaa). Avoimissa vastauksissa ilmenivät kirjastojen väliset erot. Muutamassa kirjastossa ILkehykset oli ehditty ottaa jo käyttöön opetustyössä, kun taas osassa kirjastoja IL-kehyksiä ei vielä tunnettu riittävästi, jotta niitä olisi voitu hyödyntää.

Informaatiolukutaidon kehystä kuvataan kynnyskäsitteillä (threshold concepts), tietokäytännöillä (knowledge practices) ja dispositioilla (dispositions). Kynnyskäsitteet ovat saaneet alkunsa vuosina 2013-2014 Delfoimetodilla toteutetussa tutkimuksessa, jossa asiantuntija-panelistit työstivät 50 potentiaalista käsitettä ja valitsivat niistä lopuksi 6 sopivinta informaatiolukutaitoa parhaiten kuvaavaa kynnyskäsitettä. (Townsend, Hofer, Hanick, \& Brunetti, 2016, s. 23.) Informaatiolukutaidon kehykset (frames) tai kynnyskäsitteet sisältävät esimerkiksi (Kuva 3 ) tieteenalan asiantuntijuuden ja auktoriteetin kriittistä arviointia (authority is constructed and contextual), 


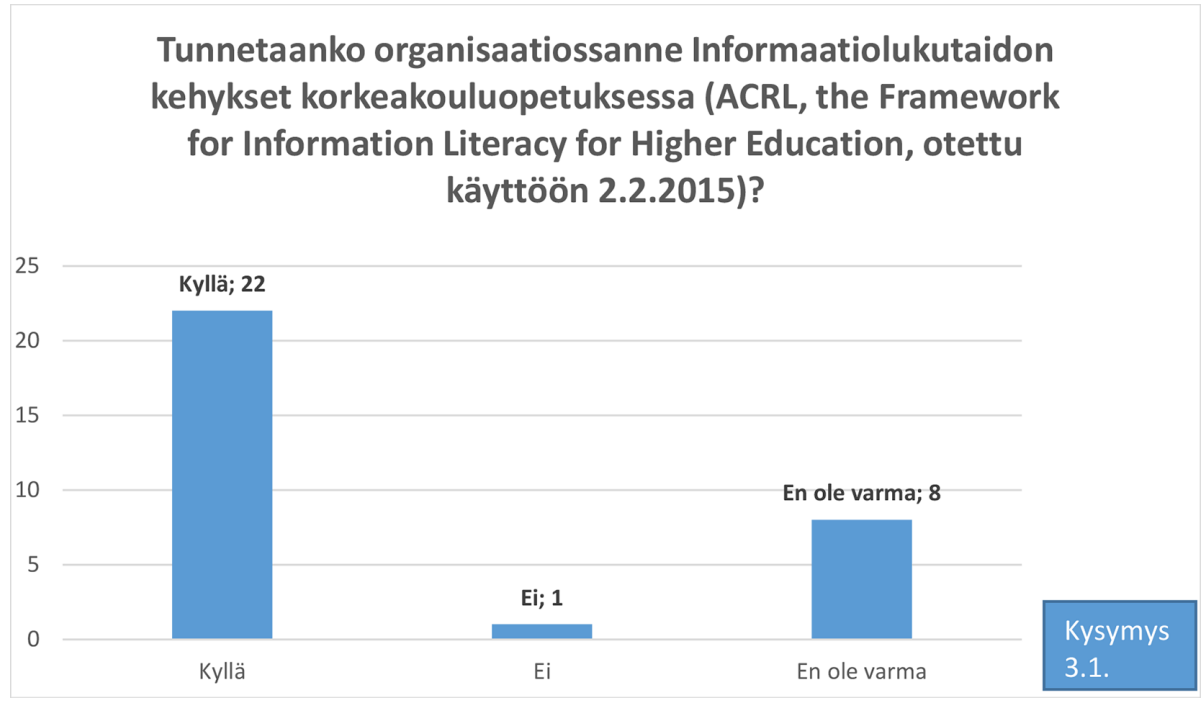

Kuva 2: IL-kehysten (ACRL 2015) tuntemus.
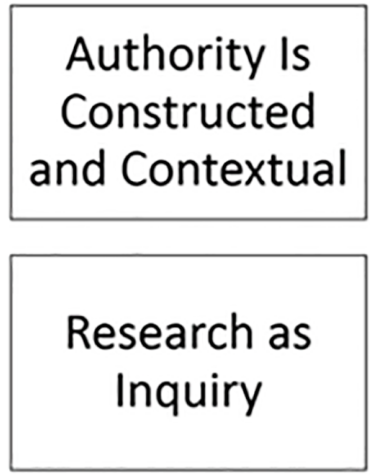
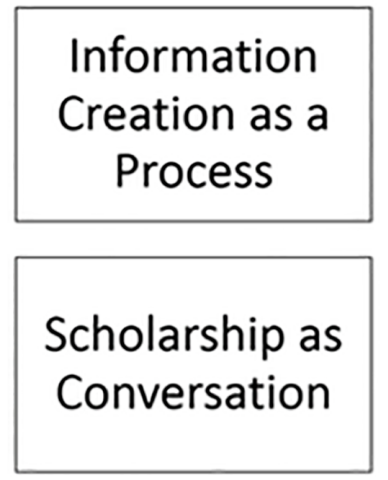

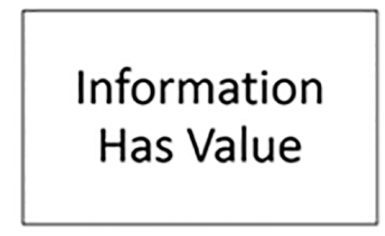

Searching as

Strategic

Exploration

Kuva 3: Informaatiolukutaidon kynnyskäsitteet tai kehykset (Information Literacy Threshold Concepts or Frames, ACRL 2015)

tiedon tuottamisen analysointia (information creation as a process), tekijänoikeuksien kunnioittamista (information has value), tutkivaa oppimista (research as inquiry), vuorovaikutuksen tärkeyttä tieteen tekemisessä (scholarship as conversation) ja tiedonhankintaa (searching as strategic exploration).

Informaatiolukutaidon kehyksen kannalta keskeisiä käsitteitä ovat kriittinen informaatiolukutaito (critical information literacy) ja metalukutaito (metaliteracy). Kriittinen informaatiolukutaito on ajattelu- ja opetustapa, joka tar- 
koittaa esimerkiksi tiedon tuottamisen prosessien kyseenalaistavaa ja analysoivaa tarkastelua (Foasberg, 2015, s. 709; Keller, 2016, ss. 111-112). Mackeyn ja Jacobsonin mukaan metalukutaito haastaa perinteisen informaatiolukutaidon, koska useiden lukutaitojen huomioiminen korostaa taitolistojen sijaan aktiivista tiedon tuottamista ja jakamista vuorovaikutteisissa verkkoyhteisöissä. (Mackey \& Jacobson, 2011, s. 64.)

Patrick S. Keller ja Leslin H. Charles ovat tutkineet, kuinka informaatiolukutaidon kehys on otettu vastaan kirjastoissa. Leslin H. Charlesin tutkimukseen osallistui 34 kirjastoalan asiantuntijaa New Jerseystä. Charles oli kiinnostunut informaatiolukutaidon opetuksen koordinaattoreiden näkökulmista ja kokemuksista informaatiolukutaidon kehykseen liittyen. Tutkimukseen osallistuneista 28 \% odotti lisää esimerkkejä informaatiolukutaidon kehyksen käyttöönotosta, 50 \% oli hyödyntänyt IL-kehyksiä kirjastoalan kollegojen kanssa ja 22 \% oli käyttänyt IL-kehyksiä tiedekunnan kanssa. (Charles, 2017, s. 226.)

Patrick S. Kellerin väitöskirjatutkimukseen osallistui 138 akateemista kirjastoalan asiantuntijaa. Heistä 32 oli kirjastonjohtajia (library deans) ja 106 kirjastoalan asiantuntijoita (assessment librarians and instructional librarians). Keller oli kiinnostunut informaatiolukutaidon kehyksen vaikutuksista. Hän analysoi kyselyn vastaukset jakamalla ne haasteisiin ja etuihin. Yhtenä keskeisenä haasteena nähtiin kirjastojen yksittäiset lähiopetukset (one-shot sessions), joihin informaatiolukutaidon kehyksen sisältämistä asioista voidaan ottaa mukaan vain hyvin pieni osa. Toisaalta informaatiolukutaidon kehyksen etuna nähtiin mahdollisuus keskustella uudella tavalla informaatiolukutaidosta tiedekunnissa ja laitoksilla. IL-kehys korostaa informaatiolukutaidon opetuksen kuuluvan koko korkeakouluyhteisölle. (Keller, 2016, ss. 22, 69, 106 ja 119.)

Christine Bombaron mukaan kirjastoalan asiantuntijat suhtautuvat ILkehyksiin kahdella tavalla. "Philosopher librarians" tarkastelevat IL-kehyksiä teoreettisesti ja "Practical librarians" pragmaattisesti. (Bombaro, 2016, ss. 555-556.) Myös Kellerin tutkimuksen tuloksissa kirjastoalan asiantuntijoilla oli pragmaattisia ja teoreettisia näkökulmia (Keller, 2016, ss. 115-119). Charlesin tutkimuksessa 65 prosenttia vastaajista oli epävarmoja IL-kehysten soveltamisesta käytäntöön. He kaipasivat konkreettisia esimerkkejä, työpajoja ja konferensseja saadakseen lisää varmuutta miten hyödyntää IL-kehyksiä. (Charles, 2017, s. 228.) Myös Syvälahden ja Asplundin toteuttaman kyselyn vastaajista löytyi pragmaatikkoja, jotka kaipasivat käytännön esimerkkejä ja ideoita siitä, miten IL-kehyksiä voisi soveltaa käytäntöön:

"Kehyksiin sisältyvät asiat on osin kuvattu epämääräisesti. Käsitteitä on vaikea ymmärtää. Vaadittavia taitoja ei enää kuvata yhtä selkeästi kuin aikaisemmissa standardeissa." 
"2015 kehyksiin tulleisiin uusiin sisältöihin liittyvät käytännön pedagogiset esimerkit hyödyttäisivät kaikkia kirjastoja tiedonhankinnan opetuksessa."

Osa suomalaisen kyselyn vastaajista näki IL-kehykset mahdollisuuksia tarjoavina:

"Uudet IL-kehykset ottavat huomioon tiedon eri muodot sekä käyttäjien erilaiset ja muuttuvat tiedontarpeet. Kehykset tukevat tiedonhankintataitojen osaamista ja täten auttavat pärjäämään tämän päivän informaatioympäristössä.”

\section{IL-kehykset käytännön opetustyössä}

Kellerin mukaan informaatiolukutaidon kehys (ACRL, 2015b) tarjoaa kokonaisvaltaisen lähestymistavan osaamistavoitteiden suunnitteluun, koska IL-kehyksissä ei ole tarkasti yhdessä sovittuja osaamistavoitteita vaan opettaja voi räätälöidä keskeiset tavoitteet kohderyhmän mukaan. Informaatiolukutaidon kehyksessä oppimista kuvataan prosessina noviisista asiantuntijaksi. Foasbergin mukaan tämä kuvaa paremmin oppimisprosessia kuin ideaalikuva informaatiolukutaitoisesta henkilöstä, joka hallitsee kattavasti informaatiolukutaidon standardien taitolistaukset. (Foasberg, 2015, s. 711; Keller, 2016, s. 37.)

Syvälahden ja Asplundin toteuttamassa kyselyssä kolme informaatiolukutaidon kehystä nousi selkeästi suosituimmaksi (Kuva 4). Suosituin IL-kehys oli "Information creation as a process". Vastaajista 24 eli $77 \%$ oli sitä mieltä, että sitä voisi parhaiten hyödyntää opetuksen suunnittelussa. Vastaajista $65 \%$ eli 20 piti hyödyllisinä IL-kehyksinä "Information has value" ja "Searching as strategic exploration". "Research as inquiry" -kehys sai 13 mainintaa (42\% vastaajista piti tätä hyödyllisenä), "Authority is constructed and contextual" 12 mainintaa (39 $\%$ vastaajista) ja "Scholarship as conversation" sai 11 mainintaa (36 \% vastaajista).

Suomalaisessa kyselyssä Syvälahti ja Asplund kartoittivat vastaajien näkemyksiä siihen, miten hyvin IL-kehykset tuovat esiin opiskelijoiden tarvitsemaa osaamista. Työelämätaidot ja hektisesti muuttuva tietoympäristö ovat ajankohtaisia teemoja korkeakoulujen opetuksessa, ja näihin vaatimuksiin myös tiedonhankinnan opetuksen tulee vastata. Kyselyn vastauksissa nousi esiin, että dynaaminen tietoympäristö on IL-kehyksissä hyvin esillä. Lähes puolet eli $48 \%$ (15 


\section{The most appropriate IL frame/IL frames (2015) for your IL courses}

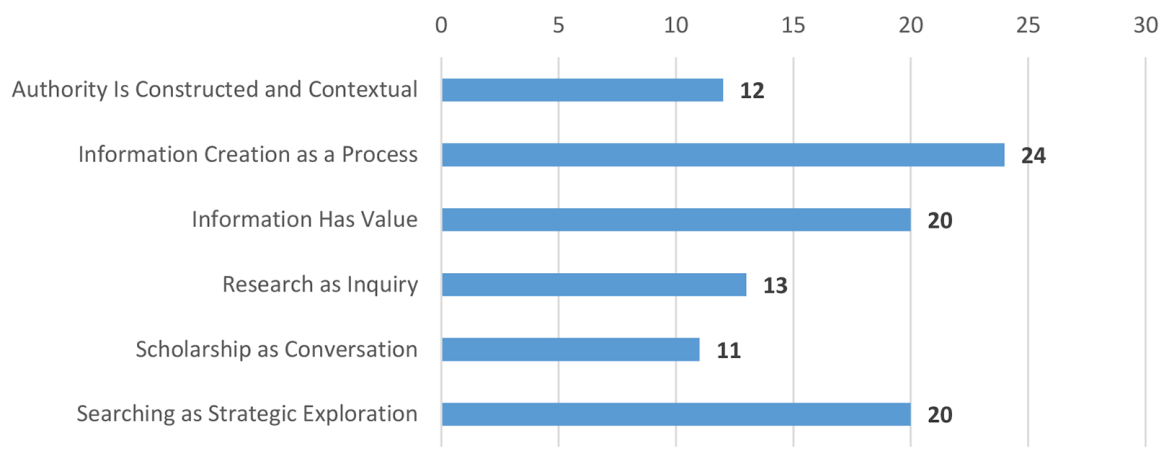

घ 4.2 Please select the most appropriate IL frame/IL frames (2015) for your IL courses (You may select several options 0-6)

Kuva 4: Hyödyllisin IL-kehys tiedonhankinnan opetuksen kehittämisessä.

vastaajaa) oli sitä mieltä, että IL-kehykset kuvaavat nopeasti muuttuvassa tietoympäristössä vaadittavia taitoja erittäin hyvin ja lähes puolet eli 15 (48 \% vastaajista) sitä mieltä, että ne kuvaavat niitä jonkin verran. Yhdessä avoimessa vastauksessa kuvattiin IL-kehyksiä:

"Uudet kehykset sopivat opiskelijoiden kohtaamaan dynaamiseen tietoympäristöön paremmin. Verkostojen merkitystä informaatio- ja ajattelutaidoissa täytyy korostaa. Samoin tärkeitä ovat relevantit tiedon käyttötilanteet ja verkostot."

Työelämälähtöisyys on suomalaiskorkeakouluissa ollut eräs osaamisperustaisen opetussuunnitelmatyön näkökulmista (Mäkinen \& Annala, 2010). Tiedonhankintataitojen merkitys työelämässä on korostunut myös valmistuneille tehdyissä kyselyissä. Aarresaari-verkoston uusimmassa kyselyssä maisterit arvioivat viisi vuotta valmistumisensa jälkeen nykyisessä työssään tarvitsemiaan taitoja ja osaamista ja miten hyvin yliopisto-opiskelu on kehittänyt noita taitoja tai osaamista. Tiedonhankintataidot on yhtenä arvioitavana taito- ja osaamisalueena. (Aarresaari, 2016.) Kirjaston asiantuntijat ovat korkeakouluyhteisössä yhtenä tärkeänä toimijana mukana vaikuttamassa siihen, millaisiksi opiskelijoiden työelämävalmiudet muodostuvat (Asplund, 2011). Syvälahden ja Asplundin toteuttaman kyselyn tulosten mukaan työelämävalmiudet eivät ole vastaajien mielestä riittävästi IL-kehyksissä esillä. Noin 74 prosenttia (23 vastaajaa) valitsi vaih- 
toehdon "jonkin verran" ja vain 23 prosenttia (7 vastaajaa) valitsi vaihtoehdon "erittäin hyvin".

Suomalaiseen kyselyyn vastanneista korkeakoulukirjastoista 12 (39 \% vastaajista) oli hyödyntänyt opetuksen kehittämisessä informaatiolukutaidon kehyksiä (ACRL, 2015b) ja 19 (61 \% vastaajista) ei ollut vielä ottanut IL-kehyksiä käyttöön. Kyselyn vastauksissa nousi esille hyviä käytäntöjä ja konkreettisia toteutuksia. IL-kehyksien avulla oli esimerkiksi kehitetty verkko- ja lähiopetuksia. Korkeakoulukirjastoissa informaatiolukutaidon kehyksiä hyödynnetään opetuksen eri vaiheissa eri tavoin. IL-kehysten voidaan nähdä tukevan akateemiseen asiantuntijuuteen kasvua vähitellen opintojen aikana. Osa IL-kehyksistä tai niiden osa-alueista kuvaa sitä osaamista ja tutkimuksellista valmiutta, mitä opiskelijoilta vaaditaan vasta opiskelun edetessä pidemmälle. Osasta vastauksista välittyy ajatus siitä, että informaatiolukutaidon kehyksistä löytyy ammennettavaa lisää tulevaisuudessa, sillä opetuksen kehittäminen on jatkuva prosessi.

Niissä korkeakoulukirjastoissa, joissa informaatiolukutaidon kehys (ACRL, 2015b) oli jo otettu käyttöön, näkyi muutamia yhteisiä linjoja. IL-kehyksiä on hyödynnetty, kun yliopiston opetussuunnitelmat uudistuvat tai opetussuunnitelmatyötä on tehty dynaamisesti muuttamalla jo olemassa olevia toteutuksia:

"IL-opetuksen toteutuksia on muutettu huomioimalla uudet kehykset. [Hyödynnetty] uuden OPSin suunnittelussa (otetaan käyttöön syksyllä 2017)”.

Osassa korkeakoulukirjastoja on käytetty IL-kehyksiä osaamistavoitteiden työstämisessä, ammatillisen keskustelun ja työskentelyn apuna, sekä laajemmin tutkinto-ohjelmien kehittämistyössä:

"Koulutusohjelmien kanssa keskusteltaessa osaamistavoitteita on käytetty pohjana opetuksen suunnittelussa. Osaamistavoitteita on muotoiltu kehysten avulla."

IL-kehysten on nähty tarpeellisella tavalla laajentavan sitä näkemystä, millaisia oman alan osaamistarpeita opiskelijoilla on ja mihin suuntaan myös tiedonhankinnan opetusta voisi kehittää:

"Oman opiskelualan tiedontuottajien, tutkijoiden ja asiantuntijoiden tietäminen on osa IL-osaamista (välineinä verkko, lehdet, tutkimukset, some...); alan tiedon ja kulloisenkin tiedontarpeen tunnistaminen ja yhteensovittaminen (esim. video, akateeminen teksti); tiedonhankinnan prosessimaisuus myös - kaikki ovat jollakin tavalla jo mukana IL-opetuksessamme." 


\section{Pohdinta}

Kati Syvälahden ja Janika Asplundin toteuttamasssa kyselyssä annettiin korkeakoulukirjastoille mahdollisuus jakaa käytännön kokemuksia ACRL:n vuonna 2015 julkaisemasta informaatiolukutaidon kehyksestä. Analysoitaessa ILkehyksiä on tärkeää muistaa informaatiolukutaidon standardien (ACRL, 200o) pitkä historia ja keskeinen rooli informaatiolukutaidon opetus- ja tutkimustyössä. Suomalaisessa kyselyssä ilmeni, että lähes kaikissa vastanneissa korkeakoulukirjastossa tunnettiin IL-standardit (30 vastaajaa) ja 25 oli hyödyntänyt niitä opetustyössä. Kyselyyn vastanneista kirjastoista 22:ssa tunnettiin IL-kehykset, ja 12 oli jo hyödyntänyt IL-kehyksiä opetustyössä. Avoimissa vastauksessa ilmeni, että osalle vastaajista kysely toimi myös muistutuksena informaatiolukutaidon kehyksien olemassaolosta.

ACRL Board of Directors päätti kesäkuussa 2016 luopua vuonna 2000 julkaistuista informaatiolukutaidon standardeista. Yhteenvetona Yhdysvalloissa käydystä keskustelusta voi todeta, että kirjastoalan asiantuntijat toivovat ILstandardien ja IL-kehyksien toimivan jatkossa rinnakkaisina dokumentteina. Syvälahden ja Asplundin toteuttamassa kyselyssä nousi myös esiin, että osa suomalaisista korkeakoulukirjastoista hyödyntää opetuksen suunnittelussa sekä ILkehyksiä että IL-standardeja:

\section{"Koulutukset ovat yhdistelmä vuoden 2000 ja 2015 kehyksistä, mutta painotus on uudemmissa."}

Informaatiolukutaidon standardit (ACRL, 2000) ovat toimineet nimenomaan yhteistyön välineenä, joten korkeakoulukirjastoissa halutaan hyödyntää myös IL-kehyksiä yhteistyössä opettajien, tutkijoiden, tiedekuntien, laitosten tai koulutusohjelmien kanssa. Osa suomalaiseen kyselyn vastaajista koki, että informaatiolukutaidon kehykset ovat hyvin teoreettinen dokumentti ja käytännön esimerkkejä kaivattiin lisää. Kriittinen suhtautuminen IL-kehyksiin näkyi kysymyksessä, jossa vastaajat pohtivat aikovatko hyödyntää IL-kehyksiä tulevaisuudessa. Kyselyyn vastanneista 58 \% (vastaajista 18 ) aikoi hyödyntää IL-kehyksiä tulevaisuudessa opetuksen kehittämiseen ja yhteistyöhön tiedekuntien kanssa. Kyselyyn vastanneista kirjastoista $32 \%$ :ssa (10 vastaajaa) ei oltu varmoja ILkehyksien käytöstä ja 10 \% (kolme vastaajaa) ei aikonut hyödyntää kehyksiä (Kuva 5). Kyselyn tulosten perusteella voi todeta, että informaatiolukutaidon kehyksien käyttöönottoa helpottaisi niiden kääntäminen suomeksi. Virallinen käännöstyö edellyttäisi erilaisten asiantuntijoiden osaamisen yhdistämistä esimerkiksi hankerahoituksen avulla. Tällä hetkellä kirjastoilla on käytössä lähinnä erilaisia versioita pelkkien IL-kehyksien otsikoiden käännöksistä. Jotta infor- 


\section{Aiotteko hyödyntää IL-kehyksiä (2015) yhteistyössä tiedekuntien kanssa ja suunnitellessanne IL-opetusta ja sen toteutusta?}

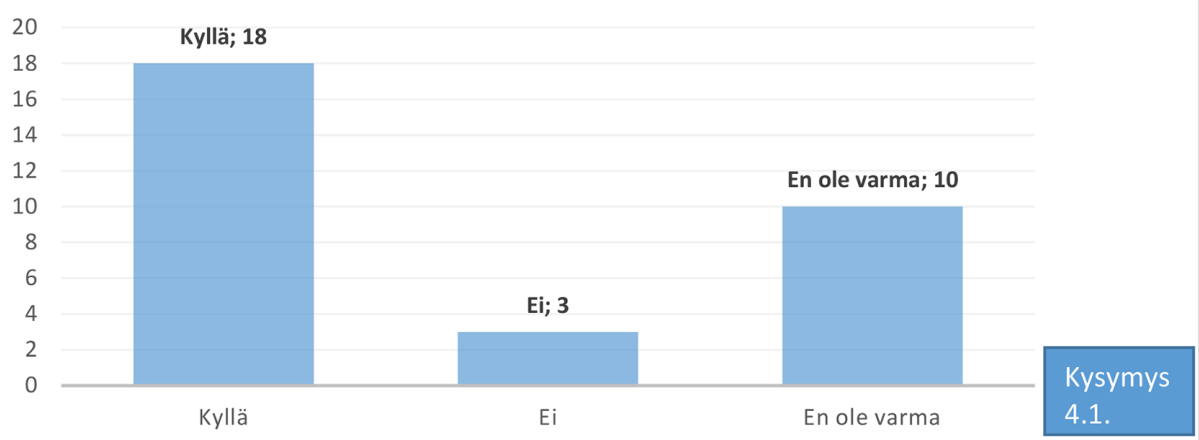

Kuva 5: IL-kehysten hyödyntäminen tiedekuntayhteistyössä.

maatiolukutaidon kehystä voisi hyödyntää parhaalla mahdollisella tavalla tiedonhankinnan opetustyössä, koko dokumentti olisi tärkeää kääntää suomeksi.

Yhdysvalloissa on otettu käyttöön The ACRL Framework for Information Literacy Sandbox (ACRL, 2015a) sivusto, jossa voi avoimesti jakaa käytännön ideoita ja opetusmateriaaleja liittyen IL-kehyksiin. Tulevaisuudessa on tärkeää, että myös suomalaiset korkeakoulukirjastot jakavat konkreettisia esimerkkejä hyvistä käytänteistä esimerkiksi verkossa, seminaareissa tai työpajoissa. Tiedon ja kokemusten avoin jakaminen auttaa IL-kehysten käyttöönottoa kirjastojen opetustyössä.

Kun tutkitaan tiedonhankinnan opetuksen vaikuttavuutta, voisi olla tarpeellista pohtia, miten eri vaiheissa antamamme informaatiolukutaidon opetus siirtyy opiskelijoiden ja tutkijoiden todelliseen käyttäytymiseen esimerkiksi opiskeluun tai tutkimukseen liittyvissä tilanteissa, joissa tieto-osaamista tarvitaan. Annikki Roosin väitöskirjassa korostetaan tiedonhankinnan olevan tehtäväsidonnaista. Tiedonhankinta liittyy tutkijoilla laajempaan työkokonaisuuteen, josta tiedonhankinta on vain osa, ja tuo laajempi kokonaisuus saattaa olla hyvinkin kollaboratiivista. (Roos, 2016, s. 6; Talja \& Nyce, 2015). Myös informaatiolukutaidon kehyksissä korostetaan yhteistyöaspektia, verkostojen merkitystä ja kontekstisidonnaisuutta. Tulevaisuudessa olisikin mielenkiintoista tarkastella informaatiolukutaidon kehyksiä suhteessa tutkijayhteisön tietokäyttäytymiseen ja toimintatapoihin. Annikki Roosin väitöskirjassa ilmeni, että tutkijat näkivät tiedonhakuun liittyvät taidot teknisinä kysymyksinä sekä alisteisina alan- 
mukaiselle osaamiselle ja asiantuntemukselle. He hakivat ongelmatilanteissa tutkimusyhteisön apua sen sijaan, että olisivat kysyneet ohjeita kirjaston tiedonhankinnan asiantuntijoilta. (Roos, 2016, s. 33). Tätä tukee myös Nancy Fried Fosterin tutkimus. Hän on tutkinut tutkijoita ja opiskelijoita etnografisella menetelmällä havainnoimalla tutkijoiden toimintatapoja. IL-standardien kirjastolähtöisyyttä kritisoinut Foster on sitä mieltä, että asiantuntijaverkostot, henkilökohtaiset verkostot ja yhteisön tuottama tieto ovat nykyisin entistä tärkeämpiä informaatiolähteitä. Fosterin mukaan ACRL:n IL-kehykset kuvaavat paremmin todellista tietoympäristöä, jossa tutkijoiden todellinen tiedonhankinta ei välttämättä ole lineaarista tai systemaattista, ja jossa tutkijat jakavat tai tuottavat tietoa itselleen merkityksellisissä konteksteissa. (Asplund, 2014; Fried Foster, 2014). Kirjastot voisivat tulevaisuudessa edelleen kehittää tietoasiantuntijoiden parempaa lähestyttävyyttä niin, että kirjastojen asiantuntijoiden konsultointi olisi tutkijoiden mielestä yhtä matalan kynnyksen takana kuin tutkijakollegan kanssa keskustelu. Tutkijan omaksumat tiedonhankintatavat ja kirjaston asiantuntijan ehdottamat hakutavat eivät poissulje toisiaan, vaan voisimme ajatella niitä toisiaan täydentävinä.

Jatkotutkimusta tarvitaan myös siitä, miten informaatiolukutaidon kehyksiä voitaisiin ajatella laajempana akateemisena kysymyksenä, ei vain liittyen kirjaston järjestämään informaatiolukutaidon opetukseen. Kehyksiä voisi Suomessa jatkossa analysoida laajemmin myös tieteellisen ajattelun ja akateemisen asiantuntijuuden kehittymisen näkökulmasta, kuten IL-standardeja on aikanaan tarkasteltu, ja informaatiolukutaidon opetuksen kehittäminen tulisi nähdä edelleen kirjaston ja yliopiston tiedekuntien välisenä kumppanuutena (Iivonen, Tevaniemi, \& Toivonen, 2007; Nevgi, 2007).

Kriittinen keskustelu ACRL:n informaatiolukutaidon kehyksistä jatkuu varmasti tulevaisuudessa. Informaatiolukutaidon kehyksien vahvuutena on se, että ne korostavat informaatiolukutaidon opetuksen kuuluvan koko korkeakouluyhteisölle. Tulevaisuudessa on mielenkiintoista seurata, minkälaisia vaikutuksia informaatiolukutaidon kehyksillä on korkeakouluopiskelijoiden opintoihin Suomessa ja kansainvälisesti.

\section{Lopuksi}

Artikkelissa tarkasteltiin Kati Syvälahden ja Janika Asplundin toukokuussa 2017 toteuttamaa kyselyä suomalaisille korkeakoulukirjastoille. Kyselyyn tuli vastauksia 31 korkeakoulukirjastosta. Kyselyn tuloksena ilmeni, että IL-standardit ovat olleet käytössä pitkään ja niitä on hyödynnetty yli vuosikymmenen ajan. Suurin osa korkeakoulukirjastoista tuntee uudet IL-kehykset pääpiirteissään, mutta 
IL-kehysten käyttöönotossa on vaihtelua kirjastojen välillä. Kyselyn vastauksissa näkyi, että Suomessa keskustelu informaatiolukutaidon kehyksistä on ollut maltillista ja IL-kehykset ovat olleet melko vähän esillä. Yhteenvetona kyselyn tuloksista voi kuitenkin todeta, että suomalaisissa korkeakoulukirjastoissa informaatiolukutaidon kehykset koettiin opetuksen kehittämisen kannalta tervetulleiksi ja ajanmukaisiksi. IL-kehyksien käyttöönottoa helpottaisi ACRL:n julkaiseman dokumentin kääntäminen virallisesti suomeksi esimerkiksi hankerahoituksen avulla. Hankkeen voisi toteuttaa esimerkiksi yhteistyössä useampi korkeakoulukirjasto.

\section{Lähteet}

Aarresaari. (2016). Maistereiden uraseuranta -kyselyn 2016 tulokset. https://www.aarresaari. net/uraseuranta/maistereiden_uraseuranta (luettu 9.4.2018)

ACRL. (2000). Information literacy competency standards for higher education (no longer in force). Chicago, Illinois. http://hdl. handle. net/11213/7668 (luettu 9.4.2018)

ACRL. (2015a). ACRL framework for information literacy sandbox: a platform and repository for sharing framework materials. http://sandbox.acrl.org/ (luettu 9.4.2018)

ACRL. (2015b). Framework for information literacy for higher education. Chicago, Illinois: Association of College \& Research Libraries. http://www.ala.org/acrl/standards/ilframework (luettu 9.4.2018)

Asplund, J. (2011). Tiedonhankintataitojen merkitys korostuu työelämässä - Suomen yliopistokirjastojen neuvosto. http://yliopistokirjastot.fi/tiedonhankintataitojen-merkityskorostuu-tyoelamassa/ (luettu 9.4.2018)

Asplund, J. (2014). Informaatiolukutaitoa Irlannista - pääosassa tiedonhakija. Bulletiini: Tampereen yliopiston kirjaston verkkolehti, 3(1). http://www.uta.fi/kirjasto/bulletiini/arkisto/ 2014/2014-3-7.html (luettu 9.4.2018)

Bombaro, C. (2016). The framework is elitist. Reference Services Review, 44(4), 552-563. https: //doi.org/10.1108/RSR-08-2016-0052

Charles, L. H. (2017). Embracing challenges in times of change: a survey of the readiness of academic librarians in New Jersey for transition to the ACRL framework. Communications in Information Literacy, 11(1), 221-245. https://doi.org/10.7282/T3ST7SJV

Dalal, H. (2015). An open letter regarding the framework for information literacy for higher education | ACRLog. http://acrlog.org/2015/01/07/an-open-letter-regarding-theframework-for-information-literacy-for-higher-education/ (luettu 9.4.2018)

Dempsey, M., Dalal, H., Dokus, L., \& Charles, L. (2015). Continuing the conversation: questions about the framework. Communications in Information Literacy, 9(2), 164-175. https://doi. org/0.15760/comminfolit.2015.9.2.193

Elmborg, J. (2006). Critical information literacy: implications for instructional practice. The Journal of Academic Librarianship, 32(2), 192-199. https://doi.org/10.1016/j . acalib.2005.12. 004

Foasberg, N. M. (2015). From standards to frameworks for IL: how the ACRL framework addresses critiques of the standards. Libraries and the Academy, 15(4), 699-717. https://doi.org/ 10.1353/pla.2015.0045

Fried Foster, N. (2014). Information literacy and research practices. https://doi.org/10.18665/sr. 24944 (luettu 9.4.2018) 
Iivonen, M., Tevaniemi, J., \& Toivonen, L. (2007). Informaatiolukutaidon opetus - kumppanuutta käytännössä. Teoksessa A. Nevgi (toim.), Informaatiolukutaito yliopisto-opetuksessa (ss. 147166). Helsinki: Gaudeamus.

Keller, P. (2016). The framework for information literacy: academic librarians' perceptions of its potential impact on higher education library praxes. Albuquerque: University of New Mexico. http://hdl. handle. net/1928/32307

Kuhlthau, C. C. (2013). Rethinking the 2000 ACRL standards: some things to consider. Communications in Information Literacy, 7(2), 92-97. https://doi.org/10.15760/comminfolit.2013. 7.2.139

Mackey, T. P., \& Jacobson, T. E. (2011). Reframing information literacy as a metaliteracy. College \& Research Libraries, 71(1), 62-78. https://doi.org/10.5860/crl-76r1

Mäkinen, M., \& Annala, J. (2010). Osaamisperustaisen opetussuunnitelman monet merkitykset korkeakoulutuksessa. Kasvatus \& Aika, 4(4), 41-61. https://journal . fi/kasvatusjaaika/ article/view/68239 (luettu 10.4.2018)

Nevgi, A. (2007). Yliopisto-opettaja informaatiolukutaitoon ohjaamassa. Teoksessa A. Nevgi (toim.), Informaatiolukutaito yliopisto-opetuksessa (ss. 95-106). Helsinki: Gaudeamus.

Oakleaf, M. (2014). A roadmap for assessing student learning using the new framework for information literacy for higher education. The Journal of Academic Librarianship, 4o(5), 510-514. https://doi.org/10.1016/j.acalib.2014.08.001

Roos, A. (2016). Understanding information practices in biomedicine: a domain analytical approach. Helsinki: Hanken School of Economics. http://hdl . handle. net/10138/161539 (luettu 10.4.2018)

Seeber, K. P. (2015). This is really happening: criticality and discussions of context in ACRL's framework for information literacy. Communications in Information Literacy, 9(2), 157-163. https://doi.org/10.15760/comminfolit.2015.9.2.192

Sipilä, M., Miettinen, M., \& Tevaniemi, J. (2017). Informaatiolukutaidon uudet kehykset tiedonhankintataitojen opetuksessa TTY:llä. Esitys Peda-foorumilla 17.8.2017. http://urn.fi/URN: NBN: fi: tty- 201709181889 (luettu 10.4.2018)

Syvälahti, K. (2016a). Enhancing the employability of higher education students through six frames. Teoksessa Pedaforum 2016 abstraktit. Teemaryhmä 3. Jyväskylä. https://www.jyu.fi/ koulutus/pedaforum2016/abstraktit/teemaryhma3 (luettu 17.4.2018)

Syvälahti, K. (2016b). Uudet IL-kehykset tutuksi ja käyttöön. STKS Informaatiolukutaitoseminaari. http://www.stks.fi/asiakirjat/koulutustenmateriaalit/materiaalitinformaatiolukutaito

Syvälahti, K., \& Asplund, J. (2015). Kansainväliset informaatiolukutaidon osaamistavoitteet muuttuivat - mitä, miksi ja miten? Signum, 9-13. https://journal.fi/signum/article/view/ 52210 (luettu 10.4.2018)

Syvälahti, K., \& Asplund, J. (2017a). A Finnish academic libraries' perspective on the information literacy framework. Teoksessa S. Špiranec, S. Kurbanoğlu, J. Boustany, E. Grassian, D. Mizrachi, L. Roy, \& D. Ko (toim.), Fifth European Conference on Information Literacy (ECIL) - Abstracts. Saint-Malo, France. http://bit.ly/ecil-2017-abstracts

Syvälahti, K., \& Asplund, J. (2017b). A Finnish academic libraries' perspective on the information literacy framework (esityskalvot). Fifth European Conference on Information Literacy (ECIL). Saint-Malo, France. http://bit.ly/ecil2017-syvalahti-slides (luettu 17.4.2018)

Syvälahti, K., \& Asplund, J. (2017c). Kansainväliset IL-kehykset suomalaisissa korkeakoulukirjastoissa. Kyselyn tulokset. STKS Informaatiolukutaitoseminaari. http://www. stks.fi/wpcontent/uploads/2017/11/Syvalahti_Asplund_ILkehykset_STKS-ILseminaari-2017-1.pdf 
Talja, S., \& Nyce, J. M. (2015). The problem with problematic situations: Differences between practices, tasks, and situations as units of analysis. Library \& Information Science Research, 37(1), 61-67. https://doi.org/10.1016/j.lisr.2014.06.005

Townsend, L., Hofer, A., Hanick, S. L., \& Brunetti, K. (2016). Identifying threshold concepts for information literacy: a Delphi study. Communications in Information Literacy, 10(1), 23-49. https://doi.org/10.15760/comminfolit.2016.10.1.13

Tuominen, K., Savolainen, R., \& Talja, S. (2005). Information literacy as a sociotechnical practice. The Library Quarterly, 75(3), 329-345. https://doi.org/10.1086/497311 